\title{
Crustal thickness mapping in Raipur-Katni area of Narmada-Son lineament in central India derived from 3D Euler deconvolution of magnetic data
}

\author{
G K GHOSH ${ }^{1, *}$ and C L Singh ${ }^{2}$ \\ ${ }^{1}$ Oil India Limited, Duliajan 786 602, India. \\ 2 Banaras Hindu University, Varanasi 221 005, India. \\ *Corresponding author.e-mail: gk_ghosh@yahoo.com
}

\begin{abstract}
The Narmada-Son lineament (NSL) is one of the most prominent tectonic features which divides the Indian peninsula into two subcontinents, northern and southern India since Precambrian times. The area is seismically active and geologically complex with different geological formations. Magnetic data divides the area into two parts and more prominent magnetic highs are observed near Tikwa, Mau and Amarpur regions with 800, 600 and $400 \mathrm{nT}$, respectively due to the presence of the crystalline basement rock. Tectonic resettlement and lithological changes causes upwarpment of Mahakoshal rocks. In the present study, magnetic data interpretation is carried out for locating depth of causative body and delineating structural fault/dyke boundaries using Euler deconvolution technique. Most of the faults are oriented in the ENE-WSW direction; however, few more faults are identified which are oriented in the SE to NW direction. These fault patterns suggest that the area is exaggerated by tectonic turmoil and distressed both sedimentary to basement rocks isolating the area into numerous faulted blocks. The maximum depths $(>4.5 \mathrm{~km})$ observed at Katni and Umaria area and moderate depths (between 4.0 and $4.5 \mathrm{~km}$ ) observed towards east of Katni, Ramnagar, Burwa and east of Umaria and Sarna area.
\end{abstract}

\section{Introduction}

The Narmada-Son lineament (NSL) divides the Indian peninsula into two subcontinents; northern and southern India. The area of study lies in the transition zone of NSL near Raipur-Katni area which is situated between longitude $80.25^{\circ}-81.50^{\circ} \mathrm{E}$ and latitude $23.50^{\circ}-24.37^{\circ} \mathrm{N}$. The area is located in the zone of weakness and experienced numerous tectonic turbulence commencing the Precambrian era (Ravi Shanker 1988). NSL is a sub-crustal feature that persuaded the deposition of resettlement folding of the Vindhyan (Meso-Neoproterozoic) and Gondwanas (Permo-Carboniferous-lower Cretaceous) as recommended by Auden (1949). During the tectonic disturbance, the landmasses on either side of the lineament, the Proterozoic Vindhyan rocks stirred towards north and the Gondwana sediments enthused towards south of the NSL and must have undergone comparative upright movement quite a few times during the geological past (West 1962). Narmada valley stands for a zone of tectonic truncation in regional echelon and is circumscribed by two faults; SonNarmada North Fault (SNNF) and Son-Narmada South Fault (SNSF) (Jain et al. 1995; Acharya

Keywords. Narmada-Son lineament; Euler deconvolution; structural index; source depth; Mahakoshal; Son-Narmada north fault; Son-Narmada south fault. 
and Roy 2000). Both the Bijawars rocks and Vindhyan basin which are exposed indicated upliftment of basin boundaries sinking the central axis of the basin during Vindhyan sedimentation (Krishan and Swaminath 1959). Numerous major uplift, subsidence and transcurrent motion were stopped at the end of lower Proterozoic, even though there were recurrent tensile reactivations and continued gravity faulting.

The geological formations in the study area comprise alluvium, Vindhyan (Upper Proterozoic), Gondwana (Upper Carboniferous), Mahakoshal (Upper Precambrian) and crystalline basement. The areas adjacent to the study region has been studied by various researchers (Kaila et al. 1989; Rao et al. 1992; Akhtar 1996; Murty et al. 2004; Srivastava et al. 2007); however, results are not so encouraging for source depth estimation in detail and delineation of fault/dyke boundaries in the Raipur-Katni area. The shallow depth section along the deep seismic sounding (DSS) section profile passing along the Hirapur-Mandla area (Kaila et al. 1989) which is towards the west of the westernmost part of the study area. Basement depth varies $5.0 \mathrm{~km}$ at Jabera and around $1.0 \mathrm{~km}$ at Hirapur and Mandla areas. This DSS is included here for better correlation with results carried with the present interpretation.

In the present study, magnetic data has been used to estimate source to basement depth using 3D Euler deconvolution technique. The data has been acquired by Geological Survey of India (GSI) and detailed information about data acquisition is available at Project Crumansonata (1995).

Various techniques have been used for estimating the depth of the causative sources. Spector and Grant (1970) had carried out depth estimation by using slope of the power spectral density. Marson and Klingele (1993) studied about the horizontal co-ordinates of the corners related to position of the maxima of the analytic signal. The Euler deconvolution has been used as an interpretation tool for direct determination of the source-depth from potential field anomalies. Semi-automated, Euler's deconvolution technique has been used to successive segments of a pole-reduced profile to solve simultaneously for source position and depth of source type (Thompson 1982). Thompson (1982) initially worked for the profile data and thereafter Reid et al. (1990) extended it for the three dimensional gridded data. The main advantage of the Euler deconvolution is that the causative source bodies are independent of intensity of magnetization. Based on the Euler deconvolution technique, many potential researchers interpreted the magnetic sources (Neil 1990; Neil et al. 1991; Paterson et al. 1991; Beasley and Golden 1993; Hearst and Morris 1993; Fairhead et al. 1994; Ravat 1994,
1996; Debeglia and Corpel 1997; Barbosa et al. 1999; Hsu 2002; Gerovska and Arauzo-Bravo 2003; Silva and Barbosa 2003; FitzGerald et al. 2004; Gerovska et al. 2005).

Ghosh and Singh (2011) carried out 21/2 dimensional interpretations of simultaneous gravity and magnetic data to study the various lithological formations including estimation of basement depth in this area. In the present study, magnetic data interpretation has been carried out using three dimensional approaches to get source depth locations and identification of fault/dyke/sill boundaries using Euler deconvolution technique by varying different structural index and window size. Finally to get a better meaningful solution as per expected geological model, limiting criteria is applied for accepting one of the best suitable models.

\section{Geological and tectonic setting}

Different geological formations present in the study area include alluvium, Vindhyan (Upper Proterozoic), Gondwana (Upper Carboniferous), Mahakoshal groups (Upper Precambrian) and Crystalline rocks with the granite and gneisses of different geological ages (Roy and Bandyopadhyay 1998). Vindhyan and Gondwana rocks are overlaid as supracrustal rock to crystalline rock. The Mahakoshal Group is referred as Bijawar (ca 2600$2400 \mathrm{Ma}$ ) (Kumar et al. 2005) and Mahakoshal and transitional group referred by different workers (Mathur 1954; Kedar Narain 1962; Pascoe 1965; Chakraborty et al. 1996). It is noted that the type of Bijawar of Bundelkhand is differed from the Bijawar of the Son Valley and central Narmada valley (i.e., Mahakoshal Group). A series of alkaline intrusive is observed in the Son valley area which is younger intrusive and absent in Bijawar type area. The Mahakoshals are more deformed, more folded and distributed compared to the Bijawar type of area. Bijawar stands for near shore sequence lying unconformably over the Bundelkhand granite and hence the Son valley rocks developed in a fault bounded trough.

The striking of hydrocarbon at Jabera is still undecided which might be due to the Gondwana being the source rock (Mathur 1995). The Jabera area appears as dome-shaped basin having different geological rock formations like shale, sandstone, limestone and basaltic intrusive. Oil and Natural Gas Corporation (ONGC) has carried out detailed investigation in Jabera-Damoh area of Vindhyan Basin and they drilled three exploratory wells in that region namely Jabera-1, Kharkhari-1 and Damoh-1. The well Jabera-1 drilled up to $3597.7 \mathrm{~m}$ and Damoh-1 drilled up to $3501 \mathrm{~m}$ depth. In these two wells, hydrocarbon was not found. However, 
during drilling and testing of Jabera-1 exploratory well it was perceived that there is confirmed indication of gas (Directorate General of Hydrocarbon, DGH report).

SNNF and SNSF are the two prominent faults along the NSL and traceable from Markundi to Hosangabad (Jain et al. 1995; Acharya and Roy
2000). These two faults signify inward dipping funnel shapes which look similar to the normal fault at Red Sea area (Bhattacharjee and Koide 1978). The Son and Narmada rivers course their path although they have started from the same origination. The Son river initially flows from south to north and then moves towards westward

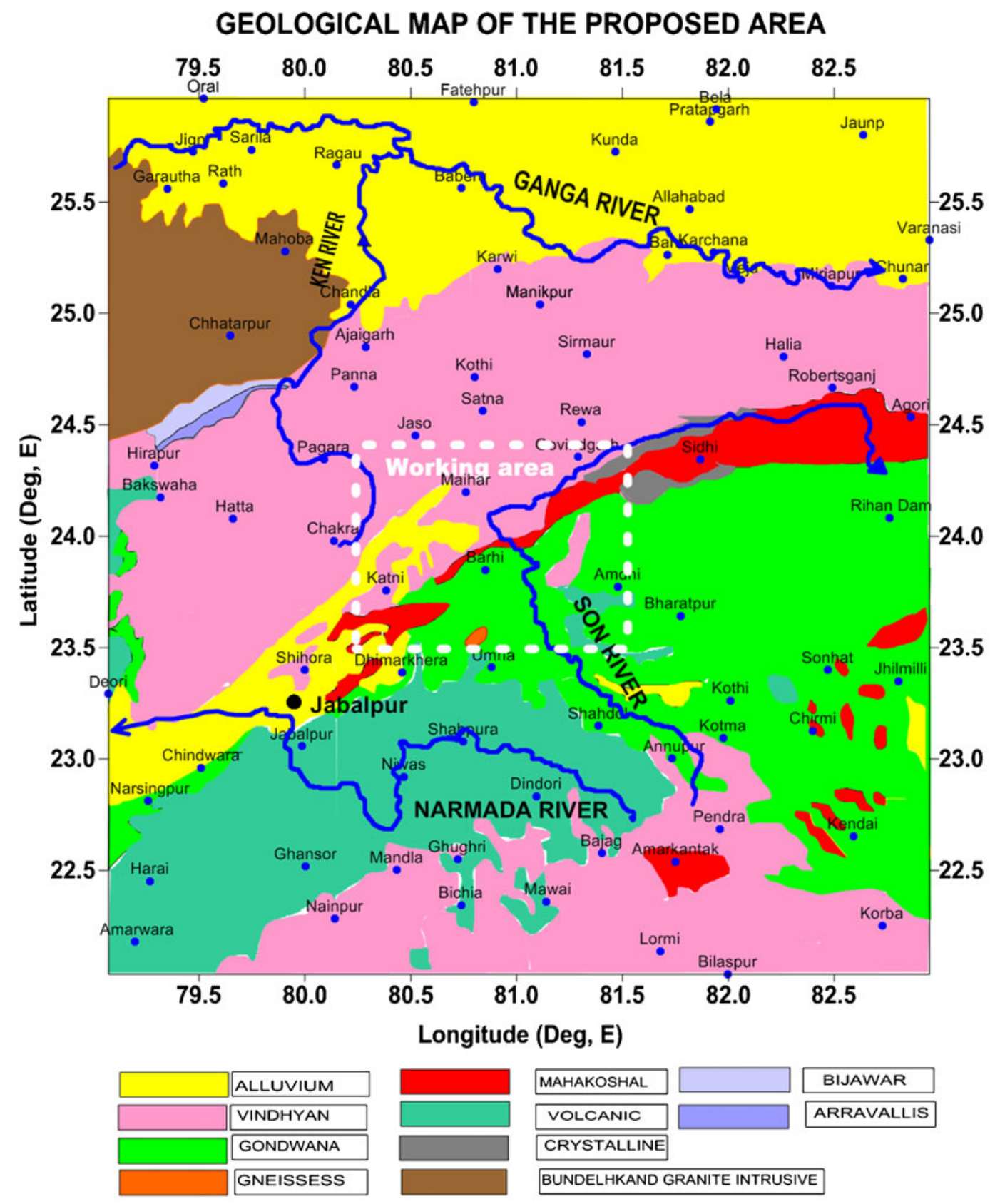

Ages: Alluvium : Quaternary; Vindhyan : Neo Proterozoic; Gondwana : Upper Carboniferous to Lower Cretaceous; Gneisses:Archaean; Bundelkhand Granitic Intrusive: Archaean Palaeo Proterozoic; Mahakoshal: Palaeo Proterozoic; Volcanic : Upper Cretaceous to Palaeogene; Crystalline: Archaean; Bijawar: Palaeo Meso Proterozoic;

Arravallis: New Prpterozoic.

Figure 1. Map of the surface geology with various formations along with Narmada, Son and Ken Rivers (after Geological Survey of India 1993). The location of the Son-Narmada North Fault (SNNF) and Son-Narmada South Fault (SNSF) are marked. 


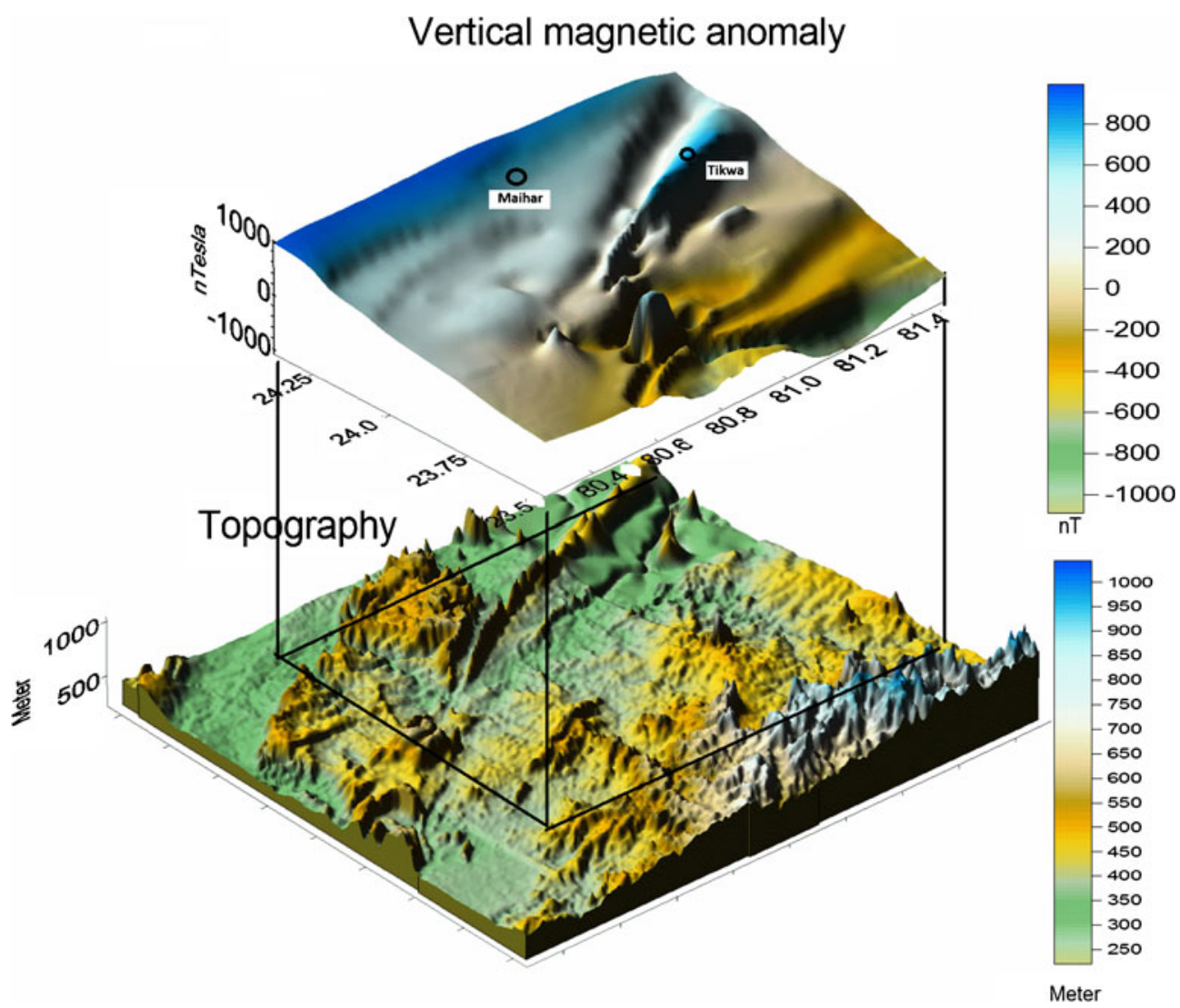

Figure 2. Map correlating topography with magnetic anomaly. Higher elevation with higher magnetic value observed in the northern part and higher elevation with lower magnetic value observed in the southern part indicate the tectonic resettlement. The high magnetic values marked near Tikwa and Maihar areas are shown in the map.

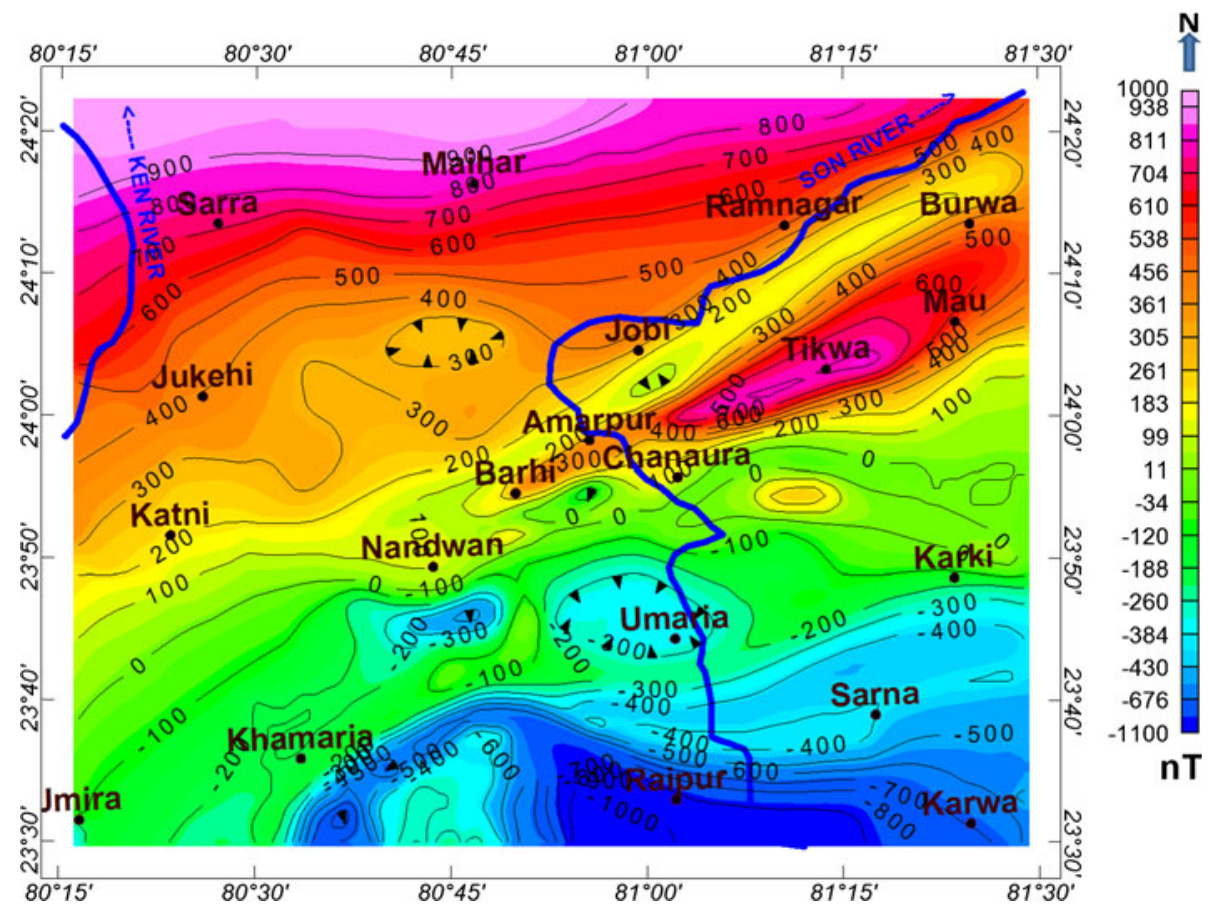

Figure 3. Map shows the magnetic anomaly of the study area. The contour interval is $100 \mathrm{nT}$. The trend of magnetic anomaly oriented in ENE-WSW direction. The Ken River and Son River locations are also indicated. 
direction (Qureshy 1981; Valdiya 1984). The exposed gneisses are equivalent to the Bundelkhand Group presenting as ensialic rift. Lamprophyre and syenite are a part of Mahakoshal group itself in the Son valley yielded age from 1810 to 1610 m.y. (Project Crumansonata 1995). The geological map of the study area shown in figure 1 represents various geological formations and river orientation. The topography of the area suggests that the region is undulated with rise and fall of surface consisting different geological formations which might be the reason for tectonic movement. The topography and the magnetic anomaly trends are both oriented in the ENE-WSW direction as shown in figure 2.

Before interpretation, magnetic dataset need to be gridded such that it should follow the aliasing phenomena. Aliasing, levelling and location errors are caused due to the short wavelength and hence by applying different filters, particularly low pass filter, resolution can be enhanced for the shallower sources. Upward continuation can also be applied to minimize the noise. The minimum curvature gridding technique has been applied for preparing the magnetic gridded anomaly with a spacing interval of $500 \mathrm{~m}$ that is half of the original observed grid interval. The magnetic anomaly for the proposed study area suggests few high and low anomalies which are shown in figure 3 .

\section{Data source and methodology}

The magnetic data has been acquired by GSI (Project Crumansonata 1995) with a grid spacing of $1.0 \mathrm{~km}$ approximately using Syntrex magnetometer with an accuracy of $0.1 \mathrm{nT}$. To delineate the fault boundary and source depth estimation, Euler deconvolution technique has been applied. The theoretical approach has been discussed here briefly.

The Euler deconvolution technique is mostly used for the direct source depth interpretation for any particular object. It uses the homogeneity equation with any potential field (gravity and magnetic) data. The Euler homogeneity (Thompson 1982) equation can be written as:

$$
\begin{aligned}
& \left(x-x_{0}\right) \frac{\partial f}{\partial x}+\left(y-y_{0}\right) \frac{\partial f}{\partial y}+\left(z-z_{0}\right) \frac{\partial f}{\partial z} \\
& =-N(f-B)
\end{aligned}
$$

where $(x, y, z)$ are the coordinates of the observation points at which the total magnetic field $f$ is measured, $\left(x_{0}, y_{0}, z_{0}\right)$ are the coordinates of the point sources of the causative body as a function of $f(x, y, z) . B$ is called as 'background' term, describing the constant contribution of the regional field. The value $N$ is referred to as the structural index (SI) and is an indicator of the geometry of a causative body. The SI is also a measure of the fall-off rate of the effect of each magnetic anomaly. The Euler equation or Euler's homogeneity equation can be expressed in equation (2)

$$
x \frac{\partial f}{\partial x}+y \frac{\partial f}{\partial y}+z \frac{\partial f}{\partial z}=N f .
$$

Under certain condition, the function $f(x, y, z)$ has a common function

$$
f(x, y, z)=\frac{G}{r^{N}}
$$

where $N$ is the SI, $G$ is a function which is not dependent on $x, y, z$ and

$$
r=\left(x^{2}+y^{2}+z^{2}\right)^{1 / 2} .
$$

Thompson (1982) correlated the role of the SI and the types of source bodies. SI is a measure of the rate of change of potential field function with respect to distance. Different types of SI is published by various authors (Thompson 1982; Reid et al. 1990; Yaghoobian et al. 1992; Stavrev 1997). SI of magnetometric bodies are $>1$ than gravimetric bodies. The different types of bodies and their SI are summarized in table 1. There is a relationship between SI and number of infinite dimension of the body. It can be generalized as

Table 1. Different structural index for magnetometric and gravimetric bodies.

\begin{tabular}{lccc}
\hline Type of source body & Dimensions & $\begin{array}{c}\text { Structural index } \\
\text { for magnetometry }\end{array}$ & $\begin{array}{c}\text { Structural index } \\
\text { for gravimetry }\end{array}$ \\
\hline Sphere & 0 & 3 & 2 \\
Vertical pipe or cylinder & 1 & 2 & 1 \\
Horizontal pipe or cylinder & 1 & 2 & 1 \\
Sheet & 2 & 1 & 0 \\
Dyke & 2 & 1 & 0 \\
Sill & 2 & 1 & 0 \\
Contact & 3 & 0 & -1 \\
\hline
\end{tabular}


for gravity and magnetic source bodies: for magnetometry, SI $=3-$ (number of infinite dimension for the source body) and for gravimetry, SI = 3 - (number of infinite dimension for the source body) -1 . For a given set of observed field data, the source depth locations $\left(x_{0}, y_{0}, z_{0}\right)$ can be estimated by solving Euler's equation for a given SI using least square inversion technique which consists of number of cells in the gridded dataset. All points are used to get within the window for Euler's equation in depth solution form. In this case, to cover up all these points, the selected data window should be large enough to cover the solution for the interest of the potential field's gridded anomaly. This inversion process gets an ambiguity for each fitted parameter for compliant and rejecting significant factor.

For a gridded dataset, Euler's depth solution provides a number of depth solutions as much the number of grid points. The derived number of solutions look spurious and may not be accepted for all these results. However, for these particular gridded datasets using boundary limiting condition, there are fewer relevant solutions which are more valid and can be accepted.

\section{Qualitative interpretation of magnetic data}

The magnetic anomaly ranges from -1100 to $1000 \mathrm{nT}$ trending in the ENE to WSW direction. The long wavelength anomalies and short wavelength anomalies reflect the deep and shallow seated features, respectively. Magnetic highs are observed at Tikwa, Mau, Burwa, Maihar and Sarra areas while lows are observed at Raipur, Umaria, Khamaria, Sarna and Karwa areas which are situated in the southern part of the study area. The highest magnetic anomaly is observed near Tikwa (900 nT) and Mau (700 nT). A plateau type feature with sharply decreasing anomaly up to $100 \mathrm{nT}$ is observed along the course of river Son. The magnetic low observed near Umaria, Sarna and Khamaria areas are oriented in the EW direction. The rivers Narmada and Son started their course from the Amarkantak hill (figure 1), however there was a sudden change in the flow of Narmada river from east to west and Son river initially towards NW and later towards NE direction. It is worth-mentioning here that presence of high undulating magnetic anomaly near Tikwa and low magnetic anomaly near Umaria, Sarna and Chanaura areas are very well discernible. Mahakoshals rocks are exposed near Khamaria, Nandwan, Chanaura, Tikwa and Mau area. The magnetic trend suddenly changes at Amarpur from NW to SE direction due to the occurrences of Mahakoshal belt which has been explained as crustal upwarpment process (Project Crumansonata 1995). NSL belt comprises metavolcanic and metasediments in a major narrow fault bounded through the upper Narmada river to middle and lower Son river valley. Both the trends of surface topography and the magnetic anomaly maps are well correlated and oriented in the ENE-WSW direction (figure 2).

Mahakoshal rocks are three types as lower Agori Formation, Middle Parsoi Formation and the uppermost Dudhmaniya Formations (Roy and Devrajan 2000). Parsoi Formations are included andalusite-bearing phyllite, hornfels, arenaceous phyllite including narrow interbands of quartzite and amphibolatite with intrusive volcanic granitoids as a form of sill and dyke. This formation is exposed in the study area. However, the granitoids contain biotite granite and tourmaline-garnet granite. These rocks contain high susceptibility which signifies as content of high magnetized rocks. In general, Mahakoshal rocks and other metasediment rocks are generally characterized by high amplitude anomalies, however moderate anomalies with broad amplitude are noted for Bijawar Group. The average magnetic susceptibility of the Mahakoshal rocks are varying from $10304 \times 10^{6}$ to $99271 \times 10^{6}$ in SI unit (Project Crumansonata 1995). This lithological vitiation occurs due to the tectonic resettlement process in the past. Gondwana rocks are partly magnetic because these sediments contain minerals, and magnetic particle causes magnetic field effect. This variation of magnetic anomaly persists in the Gondwana covered area near Umaria and Sarna area causing the presence of magnetic material. Highest magnetic anomaly (800 nT) is observed near Tikwa and it extends in the WNE-WSW direction.

\section{Results and discussion}

From the gridded magnetic anomaly dataset, three gradient grids were estimated in three different directions with respect to $\mathrm{x}$ (NS direction), $\mathrm{y}$ (EW direction) and $\mathrm{z}$ (vertically downward). Figures 4-6 are the three gradient grids in three different directions respectively. These three gradients almost oriented in ENE-WSW direction and appear similar as per magnetic field variations. The horizontal gradient ( $\mathrm{x}$ and $\mathrm{y}$ components) indicates the lateral variation of the fault/dill/dyke boundaries (figures 4 and 5) and figure 6 denotes the vertical variation. The grids are expanded to a square grid by filling the input grid before using Fast Fourier Transform methods (FFT). First vertical 


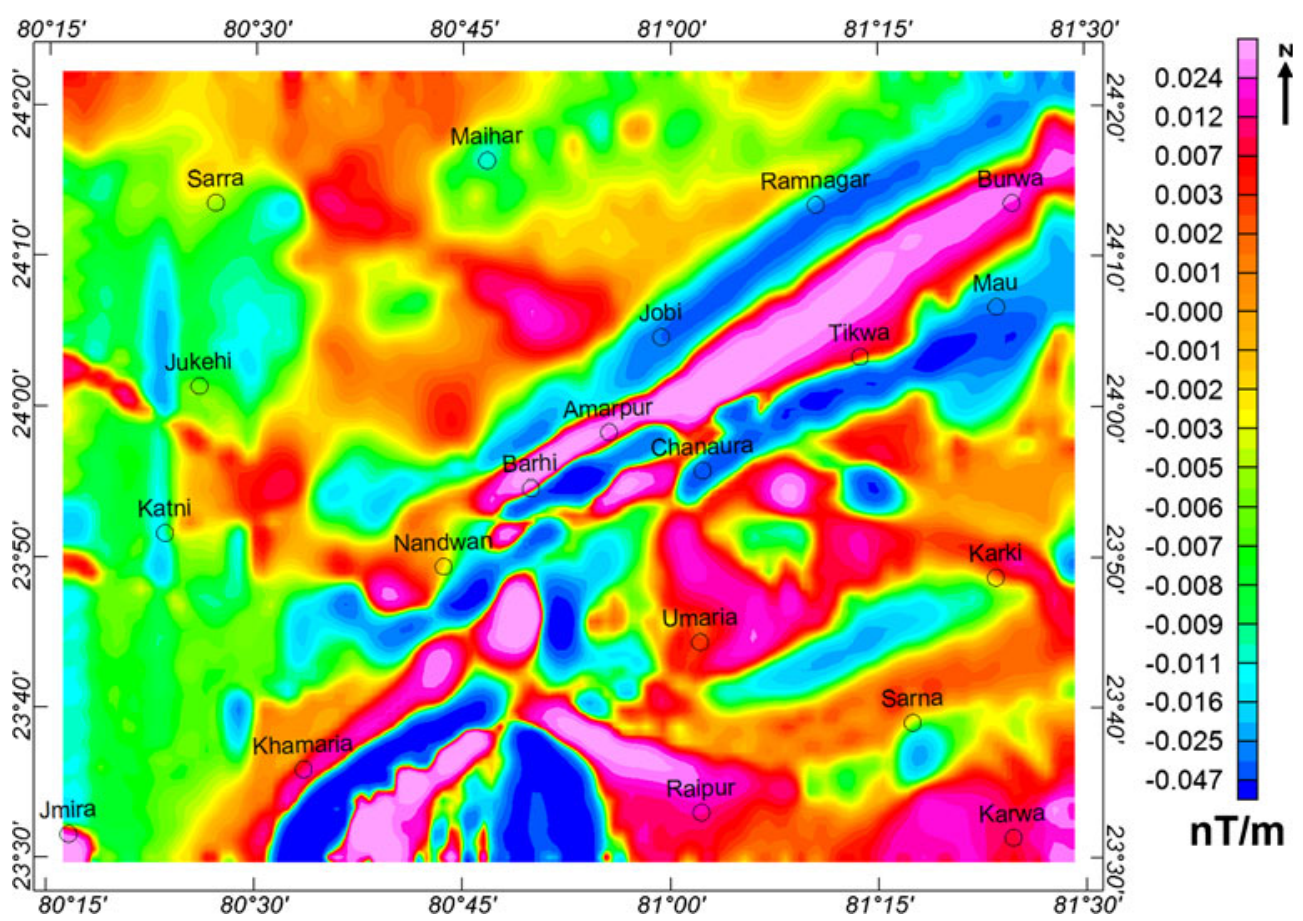

Figure 4. Map of one horizontal gradient derivative (against X component). The colour contrast shows the rate of change of magnetic field in terms of $\mathrm{nT} / \mathrm{m}$.

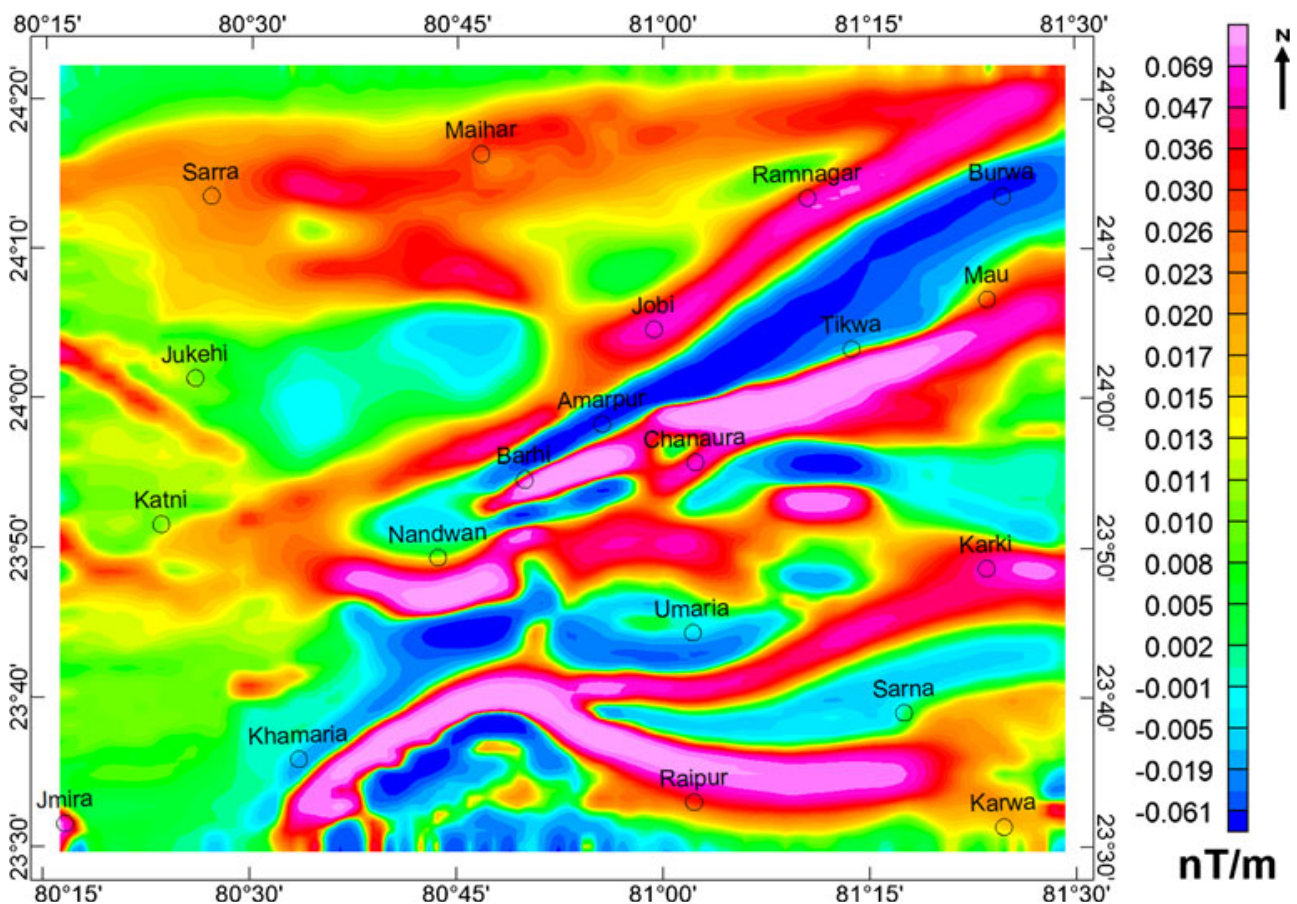

Figure 5. Map of one horizontal gradient derivative (against Y component). The colour contrast shows the rate of change of magnetic field in terms of $\mathrm{nT} / \mathrm{m}$.

derivatives using FFT method can produce undesirable side effect such as ringing and edge distortion. Hence in the present study we used $3 \times 3$ convolution filters for calculating derivatives during calculation. Analytic signals are calculated using these three gradient derivatives (figure 7) and can provide the average gradients and peak boundaries. The analytic signals show the maximum changes of magnetic field in the south-eastern part of the study area. The trend of variation 


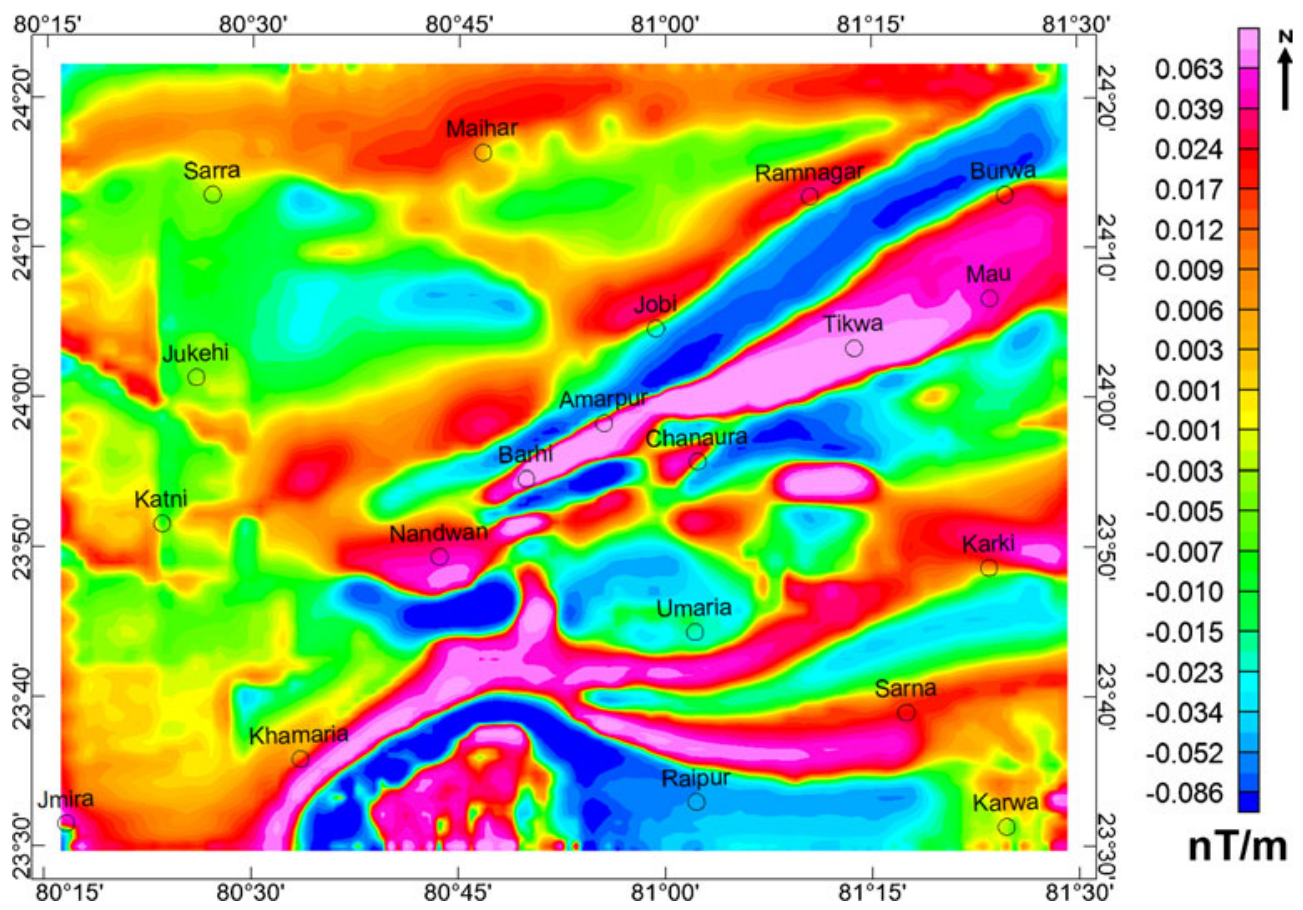

Figure 6. Map of one vertical gradient derivative (against total field). The colour contrast shows the rate of change of magnetic field in terms of $\mathrm{nT} / \mathrm{m}$.

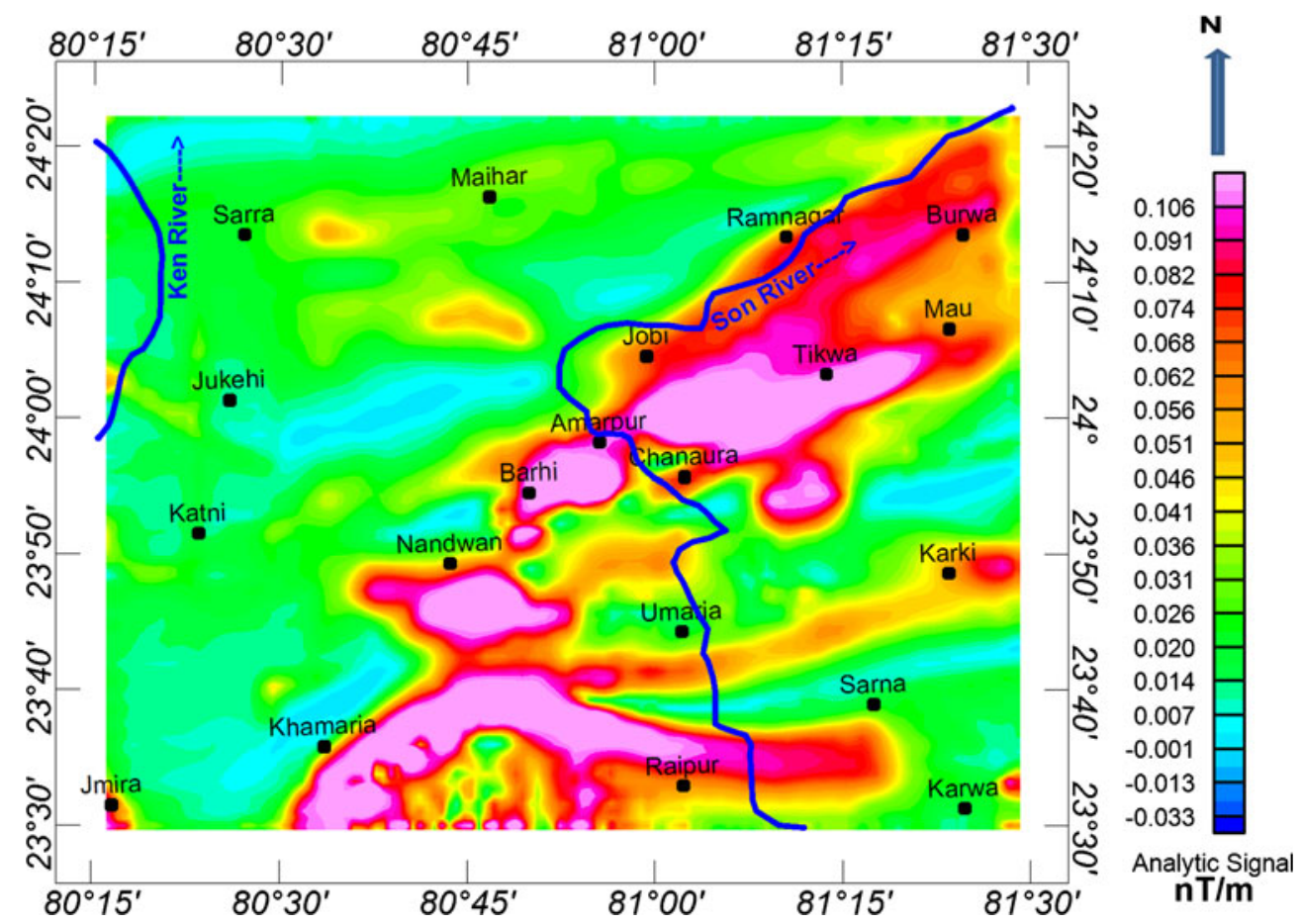

Figure 7. Map shows the analytic signal with maximum changes of magnetic field located in the south-eastern part of the study area and oriented in the ENE-SWS direction.

of the magnetic anomaly is ENE and WSW directions.

Euler deconvolution generates a large number of solutions almost one for each grid point. However, unwanted solutions are discarded by applying the depth limits and window size. Various depth solution models are generated by applying different structural indices and window size. Finally fewer 
solutions are accepted which fitted the expected geological model. After discarding the spurious solutions, it looks a simple pattern and visualized as locus of point sources which are aligned along particular directions. These circles indicate certain depth and fault/dyke boundary extension. After applying the limiting criteria as mentioned earlier, we get the better solutions. A combination of structural indices of $0,1,2,3$ and 0.5 with window sizes of $5 \times 5,10 \times 10$ and $15 \times 15$ have been studied for calculating the Euler depth solution. Excellent results are observed with the combination of SI 0 with window size 5 (figure 8). However, it can be distinguished that lower SI endow with more prominent fault/dyke/sill boundaries and higher window size provides better depth solution. Alternatively, the larger window size represents the deeper depth but lacks the fault/dyke/sill pattern. During this study, the fault orientation and the source depth locations are best demonstrated (figure 8).

The SNNF and SNSF are discernible through this study which is oriented to ENE-WSW direction and is located in the middle part of the study area (figure 9). Apart from SNNF and SNSF, there are numerous prominent faults that have been noticed in the study area. Northern Fault (SaraMaihar Fault, SMF) is located in the northern part of the area which is oriented in the EW direction. Southern Fault (Khamaria-Raipur-Karwa Fault,
KRKF) is located in the southern part, also oriented in the EW direction. The Karki Fault (KF) is located in the eastern part and oriented in the EW direction. Several granitic intrusions are speculated and located near Umaria, north of Khamaria and southeast of Chanaura. Another granitic intrusion also supposed at the east of Jukehi along the SNNF (figure 9). After studying the tectonic model plagiaristic from Euler deconvolution technique, the Karwa-Sarna-Umaria Fault (KSUF) also may persist which is located in the SW part of the area touching towards NW direction and disturbing the SNNF and SNSF. Karki-Chanaura Fault (KCF) also shows in the eastern part and oriented in the NW direction. These two faults KSUF and KCF might be moving towards SE to NW direction and colliding with SNSF and SNNF. This might be the reason why Chanaura and Amarpur areas are decidedly disturbed. During this study, it has been pragmatic that the SNNF and SNSF are not unremitting fault but seems more irregular due to dynamic movement of KSUF and KCF (figure 9). There might be the possibility of extension of SNSF due to this tectonic resettlement in the past. By integrating these entire models, it can be believed that the area is tectonically vigorous which presents a massive number of faults (figure 9). The circle size and colour mentioned in the scale indicate certain depth and fault/dyke boundary extension. The maximum basement depth estimated $4-5 \mathrm{~km}$

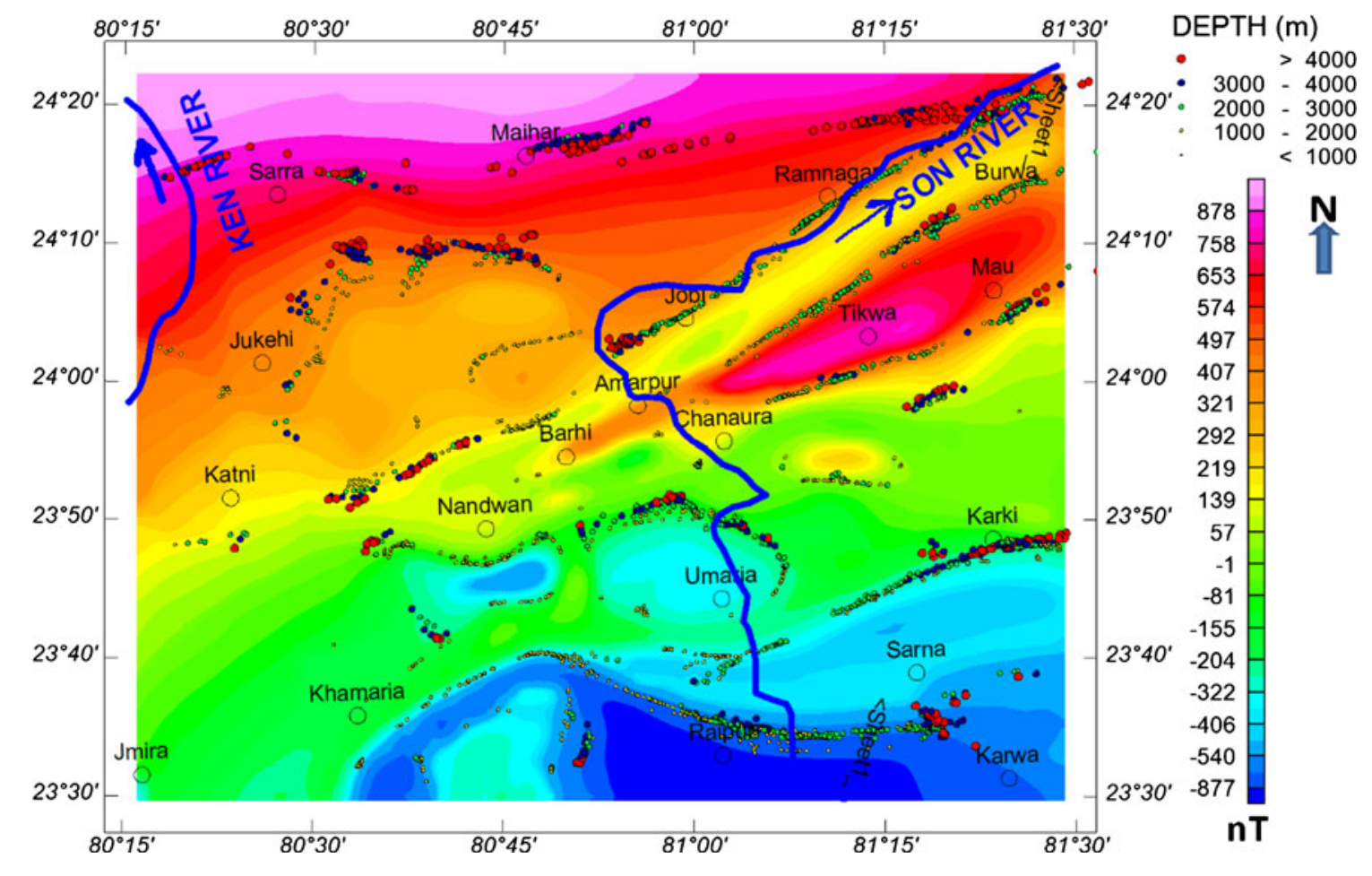

Figure 8. Euler deconvolution of magnetic data using structural index 0 and window size 5. Source depth and the cluster solutions are indicated by circle and as shown in the scale. 


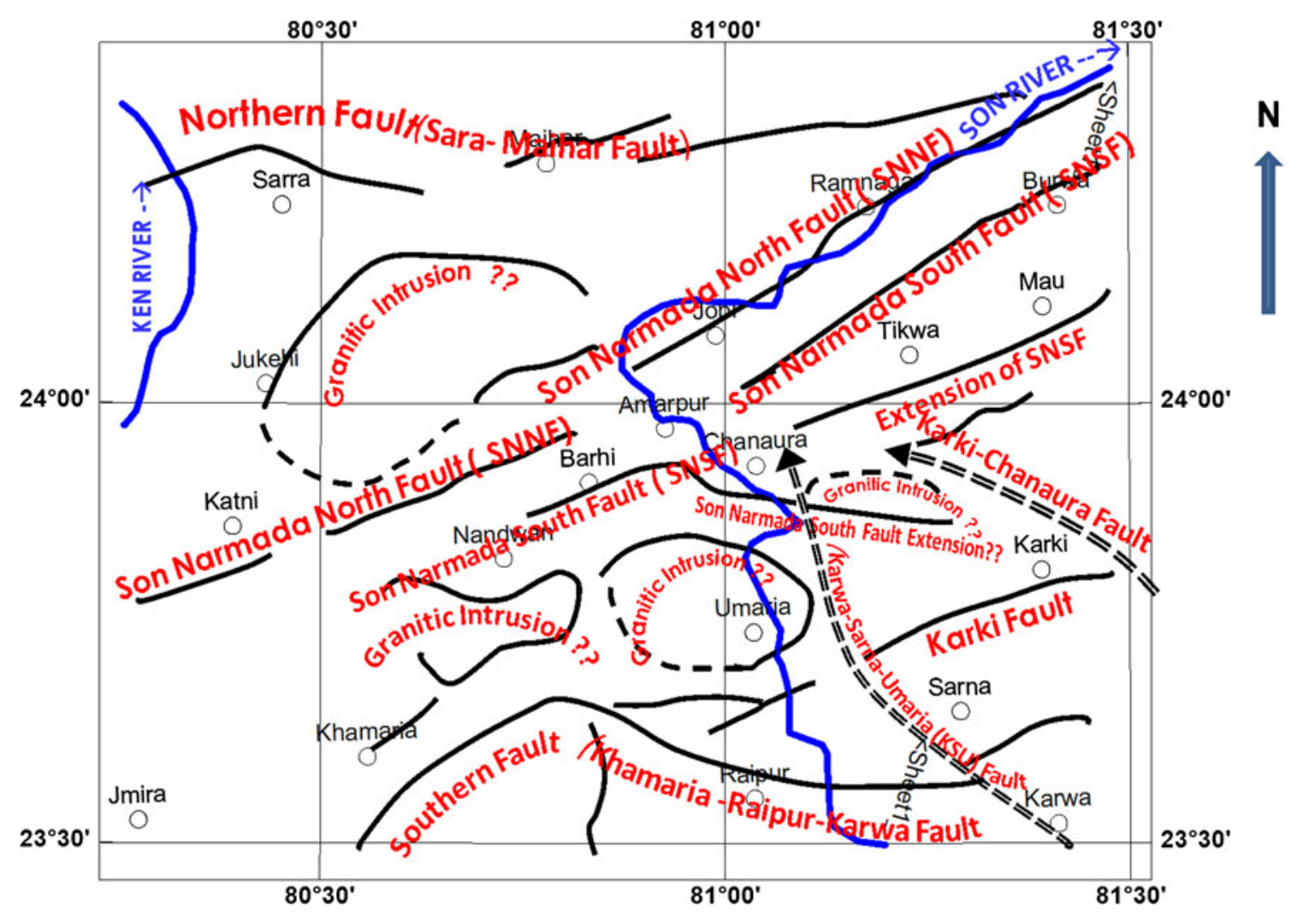

Figure 9. Interpretation of Euler deconvolution. Various fault boundaries and depths are located. SNNF and SNSF along with other significant faults are noticeable. Different granitic intrusive are also located.

and as low as $1000 \mathrm{~m}$. The maximum depths are observed at Khamaria, Tikwa, Maihar, Jukehi, Amarpur and Sarra. Few faults acknowledged are KF, SNSF, SNNF, and SMF (figure 9). Under this study, the Euler deconvolution technique lucratively estimates the source depth locations and delineates the fault boundaries in the complex transition zone area.

There is a clear stress change against the fault which is oriented in the NW to SE direction and extended from Sarna to Chanaura area (figure 9). This fault pattern proposed that the area is affected by tectonic disturbances and disturbed both sedimentary to basement rocks dividing the area into several faulted blocks. The interpreted map (figure 9) suggests that the volcanic intrusive in the past and tectonic activities with the formation of Godavari/Mahanadi causes NW-SE trend fault in the area. NW-SE trends are related to the formation of Mahanadi-Godavari graben.

\section{Summary and conclusion}

The NSL is seismically active and geologically complex prominent lineaments which divides the Indian peninsula into two parts; northern and southern India. The upliftment of Mahakoshal rocks is the primary cause of changes in magnetic anomaly. Magnetic highs are observed in the northern part at Maihar and Sarra areas and lows are observed in the southern part, namely Sarna, Karwa, Raipur and Umaria areas. The high magnetic values are observed at Tikwa (900 nT) and Mau (700 nT) areas, may be due to the upliftment of Makakoshal rocks and presence of exposed crystalline basement. The crustal resettlement in the southern part of the study area appears to be the main reason for sudden change in course of the Narmada and Son rivers, although their emerging points are from the same origination. All the three gradient components of the magnetic field (figures 4-6) show similar pattern, however, the analytical signal derived from these three gradient component look better variation of magnetic field (figure 7 ). The source depth estimates using Euler deconvolution technique, vary from 1 to $5 \mathrm{~km}$. The cluster points suggest the source depth pattern and the fault/dyke boundaries. The source depth locations and the nature of fault pattern orientation are marked and clearly identified. The SNNF and SNSF along with other relevant faults are clearly visualized from the derived source depth solutions (figure 9). It may be noted that magnetic method has its own limitation and therefore it is suggested to analyse close grid 
magnetic data under constraints from other geophysical method in order to reduce the ambiguity.

\section{Acknowledgements}

The authors are thankful to many authors of the various journals directly or indirectly for their ideas and inspiration throughout the work. Authors are also thankful to the Editor and reviewer for critically examining the paper and their valuable suggestions to improve the scientific content.

\section{References}

Acharya S K and Roy A 2000 Tectonothermal history of the central Indian tectonic zone and reactivation of major faults/shear zone; J. Geol. Soc. India 55 239-256.

Akhtar K 1996 Facies sedimentation process and environments in the Proterozoic Vindhyan basin, India; In: Recent advances in Vindhyan Geology (ed.) Bhattacharya A, Geol. Soc. India Memoir 36 127-136.

Auden J B 1949 A geographical discussion on the Satpura hypothesis and Garo-Rajmahal gap; Proc. Natl. Inst. Sci. India 15 315-340.

Barbosa V C E, Silva J B C and Medeiros W E 1999 Stability analysis and improvement of structural index estimation in Euler deconvolution; Geophysics 64 48-60.

Beasley C W and Golden H C 1993 Application of Euler deconvolution to magnetic data from the Ashanti belt, southern Ghana; Presented at 63rd Ann. Internat. Mtg., Soc. Expl. Geophys.; Expanded Abstr, pp. 417-420.

Bhattacharjee S and Koide H 1978 The origin and evaluation of rifts and rift valley structures: A mechanistic interpretation in tectonic and geophysics of continental rifts (eds) Ramberg I B and Neumann E R (England: D'Reidal Publishing Company), pp. 29-37.

Chakraborty P P, Banerjee S, Das N G, Sarkar S and Bose P K 1996 Volcaniclastics and their sedimentological bearing in Proterozoic Kaimur and Rewa groups in central India; In: Recent advances in Vindhyan Geology (ed.) Bhattacharya A, Geol. Soc. of India Memoir 36 59-76.

Debeglia N and Corpel J 1997 Automatic 3D interpretation of potential filed data using analytic signal derivatives; Geophysics 62 87-96.

Directorate General of Hydrocarbons (DGH) under Ministry of Petroleum \& Natural Gas, Govt. of India (http://www.dghindia.org).

Fairhead J D, Bennett K J, Gordon D R H and Huang D 1994 Euler: Beyond the 'black box'; Presented at the 64th Ann. Internat. Mtg., Soc. Expl. Geophys. Expanded Abstr, pp. 422-424.

FitzGerald D, Reid A and McInerney P 2004 New discrimination techniques for Euler deconvolution; Comput. Geosci. 30 461-469.

Gerovska D and Araúzo-Bravo M J 2003 Automatic interpretation of magnetic data based on Euler deconvolution with unprescribed structural index; Comput. Geosci. 29 949-960.

Gerovska D, Stavrev Y and Arauzo-Bravo M J 2005 Finitedifference Euler deconvolution algorithm applied to the interpretation of magnetic data from northern Bulgaria; Pure Appl. Geophys. 162 591-608.

Ghosh G K and Singh C L 2011 Shallow crustal configuration of the Narmada-Son lineament transition zone near the Sahdol-Katni area of central India using simultaneous gravity and magnetic observations; Pure Appl. Geophys. 168(5) 845-860.

Hearst R B and Morris W A 1993 Interpretation of the Sudbury structure through Euler deconvolution; SEG Annual Meeting, Washington DC, Extended Abstr. GM1.7, pp. 421-424.

Hsu S K 2002 Imaging magnetic sources using Euler's equation; Geophys. Prosp. 50 15-25.

Jain S C, Nair K K K and Yedekar D B 1995 Tectonic evolution of the Son-Narmada-Tapti lineament zone; Project Crumansonata Spec. Publ. 10 333-371.

Kaila K L, Murtthy P R K, Malll D M and Dixit M M 1989 The evolution of the Vindhyan basin vis-a-vis the Narmada-Son lineament, Central India, from Deep Seismic Soundings; Tectonophys. 162 277-289.

Kedar Narain 1962 Systematic mapping in parts of Dudhi and Robertsganj tehsils of Mirzapur district, U.P; unpublished Progress Report, Geological Survey of India.

Krishan M S and Swaminath J 1959 The great Vindhyan basin of northern India; J. Geol. Soc. India 1 10-30.

Kumar S, Schidlowski M and Joachimski 2005 Carbon isotope stratigraphy of the Palaeo-Neoproterozoic Vindhyan Supergroup, central India: Implications for basin evolution and intrabasinal correlation; J. Palaeontol. Soc. India $\mathbf{5 0}$ 65-81.

Marson I and Klingele E E 1993 Advantages of using the vertical gradient of gravity for 3D interpretation; Geophysics 58(11) 1588-1595.

Mathur P 1995 Precambrian emerging frontier of future exploration; Proceeding of International Petroleum conference; Petrotech 95 II 401-410.

Mathur S M 1954 Continuation of Geological Survey of area to the south of Kaimur range, Mirzapur district, U.P., unpublished Progress Report, Geological Survey of India.

Murty A S N, Tewari H C and Reddy P R 2004 2D crustal velocity structure along Hirapur-Mandla profile in central India: An update; Pure Appl. Geophys. 161 165-184.

Neil C 1990 A computer program to interpret automatically potential field data using Euler's equation of homogeneity; Unpublished M.Sc. thesis, University of Leeds, 72p.

Neil C, Whaler K A and Reid A B 1991 Extensions to Euler's method for three-dimensional potential field interpretation; (Abstract) Presented at EAEG, Florence.

Pascoe E H 1965 A manual of geology of India and Burma; Vol. I, Govt. of India Publication, Calcutta.

Paterson N R, Kwan K C H and Reford S W 1991 Use of Euler deconvolution in recognizing magnetic anomalies of pipe like bodies; Extended Abstract G/M2.6, SEG Annual Meeting, Houston, pp. 642-645.

Project Crumansonata 1995 Geoscientific studies of the SonNarmada-Tapti lineament; 371p.

Qureshy M N 1981 Gravity anomalies, isostasy and crust mantle relations in the Deccan Trap and contiguous regions, India; In: Deccan volcanism and related basalt provinces in other parts in the world (eds) Subha Rao K V and Sukheswala R N, Geol. Soc. India Memoir 3 184-197.

Rao D Ram, Babu H V and Sinha G D J S 1992 Crustal structure associated with Gondwana graben across the Narmada-Son lineament in India: An inference from aeromagnetics; Tectonophys. 212 163-172.

Ravat D 1994 Use of fractal dimension to determine the applicability of Euler's homogeneity equation for finding source locations of gravity and magnetic anomalies; In: Proc. of the Symposium on the Application of Geophysics to Engineering and Environmental Problems, Boston, 
March 1994, Environmental and Engineering Geophysical Society, Englewood, CO, pp. 41-53.

Ravat D 1996 Analysis of the Euler method and its applicability in environmental magnetic investigations; J. Environ. Eng. Geophys. 1 229-238.

Ravi Shanker 1988 Heat flow map of India and discussion on its geological and economic significance; Indian Minerals 42 89-110.

Reid A B, Allsop J M, Granser H, Millet A J and Somerton I W 1990 Magnetic interpretation in three dimensions using Euler deconvolution; Geophysics 55 80-91.

Roy A and Bandyopadhyay B K 1998 Tectonic significance of ultramafic and associated rocks near Tal in the Mahakoshal belt, Sidhi district, M.P.; J. Geol. Soc. India 32 397-410.

Roy A and Devrajan M K 2000 A reappraisal of the stratigraphy and tectonics of the Palaeo-Proterozoic Mahakoshal supracrustal belt, central India; Geol. Surv. India Spec. Publ. 57 79-97.

Silva J B C and Barbosa V C F 2003 3D Euler deconvolution: Theoretical basis for automatically selecting good solutions; Geophysics 68 1962-1968.
Spector A and Grant F S 1970 Statistical models for interpreting aeromagnetic data; Geophysics 35 293-302.

Srivastava R P, Vedanti N and Dimri V P 2007 Optimum design of a gravity survey network and its application to delineate the Jabera-Damoh structure in the Vindhyan Basin, Central India; Pure Appl. Geophys. 64 1-14, doi: 10.1007/s00024-007-0252-1.

Stavrev P Y 1997 Euler deconvolution using differential similarity transformations of gravity or magnetic anomalies; Geophys. Prospect. 45 207-246.

Thompson D T 1982 EULDPH: A new technique for making computer-assisted depth estimates from magnetic data; Geophysics 47 31-37.

Valdiya K S 1984 Aspects of tectonics focus on south-central Asia; Tata McGraw-Hill, New Delhi, 310p.

Yaghoobian A, Boustead G A and Dobush T M 1992 Object delineation using Euler's Homogeneity Equation. Location and Depth Determination of Buried Ferro-Metallic Bodies; Proceedings of SAGEEP 92, San Diego, California, pp. 613-632.

West W D 1962 The line of the Narmada and Son valleys; Curr. Sci. 31 143-144. 